This is the author's final, peer-reviewed manuscript as accepted for publication. The publisher-formatted version may be available through the publisher's web site or your institution's library.

\title{
Transnational traders: El Salvador's women couriers in historical perspective
}

Alisa Garni

\section{How to cite this manuscript}

If you make reference to this version of the manuscript, use the following information:

Garni, A. (2014). Transnational traders: El Salvador's women couriers in historical perspective. Retrieved from http://krex.ksu.edu

\section{Published Version Information}

Citation: Garni, A. (2014). Transnational traders: El Salvador's women couriers in historical perspective. Sociological Forum, 29(1), 165-188.

Copyright: @ 2014 Eastern Sociological Society

Digital Object Identifier (DOI): doi:10.1111/socf.12074

Publisher's Link: http://onlinelibrary.wiley.com/doi/10.1111/socf.12074/full

This item was retrieved from the K-State Research Exchange (K-REx), the institutional repository of Kansas State University. K-REx is available at http://krex.ksu.edu 
Transnational Traders: El Salvador's Women Couriers in Historical Perspective by Alisa Garni ${ }^{1}$

${ }^{1}$ Department of Sociology, Anthropology, and Social Work, Kansas State University, 204 Waters Hall, Manhattan, KS 66506. Telephone: (785) 532-4963; Email: amgarni@ksu.edu. 


\section{Transnational Traders: El Salvador's Women Couriers in Historical Perspective}

ABSTRACT

An estimated one-third to one-half of Salvadorans who carry remittances and goods between

El Salvador and the United States are women. Scholars studying these viajeras argue that their work simultaneously represents a break from traditional gender relations confining women to the home and an extension of gender traits that favor women in developing social ties. Although social ties are crucial to the courier trade, this argument ignores antecedents to viajeras’ work in El Salvador and suggests that transnationalism pushes women into realms of labor and physical mobility that have been gendered masculine. Using ethnographic methods, I examine the relationship between women’s historical work in El Salvador and their current work as viajeras, as well the relationship between viajeras’ experiences and those of women transnational traders in other parts of the world. My findings contribute to a small but growing body of research suggesting that instead of merely being excluded from or manipulated by global processes, many women in the Global South have expanded the realm of their activities to help shape variable forms of global capitalism. Studying how they do so sheds light on local mechanisms for combating gender inequality and promoting development.

Keywords: Migration, Development, Gender, Transnational Couriers, El Salvador, Central America 


\section{INTRODUCTION}

Working as independent entrepreneurs in an era of mass migration, many women in El Salvador negotiate a series of risks to transport news, gifts, cash, medicine, and commodities across international borders. Together with their male counterparts, these women couriers, or “viajeras,”2 deliver at least 17 percent of the migrant remittances that collectively account for three quarters of El Salvador's national foreign exchange earnings (and the equivalent of more than 16 percent of gross domestic product) (Gammage 2003, 4). ${ }^{3}$ In total, approximately 3,500 couriers annually transport an estimated 288 million dollars in cash and thousands of pounds of merchandise to and from El Salvador, while providing jobs and income to Salvadorans at home and abroad (Abarca 2004a, b; Gammage 2003; 2006; Landolt et al. 1999; United Nations Development Programme (UNDP) 2005, 135). ${ }^{4}$ Women represent one-third to one-half of all couriers in El Salvador (Gammage 2003; Mahler 1999, 710), though these ratios vary by region.

According to what I refer to as the "traditional gender relations" lens, the characteristics of the courier trade-involving “constant travel away from the home, financial and personal risks, physical stress, and so on”—are linked to "traditionally male occupations in El Salvador," and women in El Salvador become viajeras largely due their assumed advantages in cultivating social ties: "Being perceived as trustworthy and enjoying extensive social ties... are traits that favor women... and constitute a more important foundation for building the trade than the legal, financial, and social wherewithal to travel” (Mahler 1999, 700, 710-712; Gammage 2003; Gammage et al. 2005). In addition to emphasizing social ties as the main basis for women's roles

\footnotetext{
${ }^{2}$ The term “couriers” refers to both men and women, while "viajeras” refers to women only.

${ }^{3}$ Migrants also send remittances via banks, wire transfer services, and large shipping companies.

${ }^{4}$ Couriers employ assistants and buy goods from local producers or distributors.
} 
in the courier trade, this lens characterizes viajeras' work as informal relative to larger companies (banks, wire transfer and parcel services) and to men's work as couriers: Women ferry small cargo via air travel, while men additionally drive across the isthmus carrying appliances and automobiles (Gammage 2003, 2; Gammage et al. 2005, 32-35; Mahler 1999, 711). The distinction between women's and men's work in terms of formality based on cargo size, however, seems arbitrary, and social ties do not explain how women in El Salvador obtain the formal travel permits that enable them to work as couriers. How do women who rely on U.S. tourist visas launch courier businesses from El Salvador? Addressing this question may provide deeper insight into local mechanisms for combating gender inequality and promoting development.

In what follows, I argue that treating women's courier work as informal distracts from the substantial legal and financial requirements women face, how they confront such challenges, and how women’s experiences relate to changing conditions in war-torn, neoliberal El Salvador. Emphasizing “social ties as a trait that favors women” (Mahler 1999; see also Gammage 2003 and Gammage et al. 2005) inadvertently perpetuates beliefs that reinforce gender inequality while overlooking ways in which social networks might actually exclude women (Britton and Logan 2008, 108-109; Williams et al. 2012). It also obscures extensive local and historical variation in access to land, production of goods, and involvement in trade, as well as the social relations that inform and stem from these processes (for other parts of Latin America, see Barrow 1993, 181; Cupples 2004, 345; Baranyi et al. 2004; Deere and Leon 2003; Massey 1994; Massiah 1986; Momsen 1993; Safa 1995). Thus, while avoiding the problem of confusing “women’s activity with equality,” I seek to treat “the significance of gender as variable, and discover it empirically” (Miller 2001, 7-11). 
While some couriers launch businesses from the United States with the benefit of U.S. residency status (and thus can draw on assets acquired in the United States to travel relatively freely), many others rely on U.S. tourist visas that they obtain in El Salvador. To obtain visas, applicants must demonstrate to U.S. officials that they possess adequate cash savings and strong roots in El Salvador - in the form of land, businesses, capital formation, and productive activities. In one community analyzed here, women using U.S. tourist visas dominate the local courier trade. They drew on a long history of selling goods they made or harvested from household lands to launch these businesses. Working alongside other women (especially) in commerce, these women developed a passion for business and travel—as well as substantial experience in navigating risk. Although social ties are important, these previous work experiences, and women's access to land and labor, facilitated local women's involvement in the courier trade. In addition, men and women experience the social aspects of the trade differently. While men enjoy cultivating social ties, women experience social aspects of the job as stressful and something that needs to be monitored (see Menjívar 2011 on the effects of gossip).

Like Barbadian higglers (women suitcase traders) and Cape Verdean rebidantes (women grassroots traders) (Freeman 2001; 1997; Marques et al. 2001), many viajeras draw on previous business experience and a history of trade or paid wage labor to conduct transnational trade. However, whereas viajeras and rebidantes often lack alternative income earning opportunities in their countries of origin, many Barbadian higglers also work in the informatics industry, entering data for global transportation and communications firms and earning a stable salary (Freeman 2000). By contrast, with the decline of agriculture and the failure of assembly manufacturing since the early 1990s in El Salvador, 32 percent of the national labor force is under-employed and 49.8 percent of urban sector jobs are unpaid (i.e., relatives assist one another in small retail 
establishments) (National Directorate of Statistics and Census (DIGESTYC) 2008). Dollarizing the economy and implementing the Central American Free Trade Agreement (CAFTA) to bolster their investments in communications, transportation, and banking, the Salvadoran elite has reduced tariffs on imported food staples, crushing small farmers who pay a premium for fertilizers and pesticides while receiving a minimum for their grains (Hecht et al. 2005). An estimated 646,500 jobs in agriculture have disappeared while assembly manufacturing under CAFTA has provided only about 134,000 jobs, many of which are now being eliminated via trade liberalization between the United States and parts of Asia (Anner 2011; Madrid 2009, 192; c.f. Equipo Maíz 2004). Precise figures on maquila employment (more than 80 percent women) are unavailable, but it appears to represent less than 10 percent of total employment while providing wages covering only 88 percent of the basic food basket (Anner 2011, 29; DIGESTYC, 2012: xxxi; Madrid 2009, 205). Nearly 50 percent of Salvadorans live below the official poverty line (Segovia 2005, 52) and 25 percent of the population has emigrated to find work elsewhere (UNDP 2005)). Although viajeras rely on elite-dominated transportation, communication, and banking (money-lending) to work, ${ }^{5}$ they deliver goods and cash to remote communities and provide more jobs than would otherwise exist. Their trade is thus crucial for increasingly alienated and low-income Salvadorans.

OVERVIEW OF VIAJERAS’ WORK

Couriers aim to ferry as many goods as possible between El Salvador and the United States, using frequent flyer privileges to reduce luggage fees and restrictions. In addition to what

\footnotetext{
${ }^{5}$ Until 2000, couriers earned approximately \$800 per trip, traveling once or twice per month. Today, with rising airfares and travel fees, they earn half that amount (Abarca 2004a).
} 
their clients send with them as care-packages, viajeras carry merchandise to sell in either country. (U.S. based migrants pay couriers for packages sent to recipients in El Salvador and for those that Salvadorans send to them from El Salvador.) For example, heading north, couriers carry packages containing local cheeses, cream, shrimp, totopostes [corn-based breadsticks, usually bent into circular shapes], tamales, lingerie made in El Salvador (or Central America or the Caribbean), and health supplements. Couriers fill any empty space with items purchased from vendors in El Salvador to sell to migrants in the United States. Heading south, couriers carry cash (sometimes tens of thousands of dollars) and packages, this time containing clothes, shoes, and school supplies. Viajeras fill empty space with these same items, which they buy at a discount in the United States and sell to Salvadorans receiving cash remittances in El Salvador. To ensure that they are not outcompeted by banks, wire transfer or parcel delivery companies, couriers require that clients in the United States send both packages and cash with them, rather than relying on them for the former and banks or wire transfer for the latter. Cash is relatively easy to carry, and couriers make most of their money delivering cash remittances.

While the women couriers I studied own stores in El Salvador where they sell the merchandise they bring from the United States, the men do not. Shop-owners who buy merchandise from couriers must pay courier fees; viajeras who stock their own stores subsidize the cost of their trip via client fees. Men are thus less likely to bring goods from the United States to sell to shop-owners in El Salvador—both because viajeras stock their own stores and because courier fees make goods from the United States equally or more expensive than those available in El Salvador—but they are equally likely to carry goods from El Salvador to sell to migrants in the United States. Both men and women couriers usually charge about $\$ 5$ per pound of goods or per $\$ 100$ of cash remitted. Couriers often assist one another and share travel advisories 
(including information about problematic customs officials). They mediate competition by serving clients across eastern El Salvador (all the way to San Salvador) and in different U.S. cities. Although couriers cited in previous studies tended to serve only one U.S. city (Gammage 2003; Gammage et al. 2005; Mahler 1999), migrants from adjacent northeastern communities have settled across the United States, readily facilitating expansion.

Women Transnational Traders: “Traditional” versus Historical Perspectives

Research on women transnational traders in El Salvador advances what I refer to as a “traditional gender relations lens.” This lens portrays viajeras’ work as a sharp break with gendered work arrangements that prevent women from working outside the home (Gammage et al. 2005; Mahler 1999, 711-712). At the same time, it treats viajeras' work as an extension of traditional gender relations and traits, because women—supposedly confined to the home, build local social ties while men, who traditionally work outside the home, take more risks to make more money (Gammage et al. 2005, 26; Mahler 1999, 698, 700-1). For example, “during a typical day, a woman will not venture more than 100 yards from her home unless she must go into town to buy goods or take a child to the health clinic" (Mahler 1999, 698, 700); men travel alone while women always travel in groups with other women or children (Gammage et al. 2005, 26); "men own the formal stores that sell comestibles, hardware and pharmaceuticals (although tended by male and female kin), whereas women sell from makeshift stalls or from a spot on the ground. The men offer a variety of goods in their stores; the women vendedoras [vendors] sell only one commodity” (Mahler 1999, 701). By extension, these scholars find that viajeras "achieve success largely by following quite traditional gender relations: by cultivating close personal relationships with networks of kin and friends and by working in tandem with a protective complement of males” (Gammage 2003; Gammage et al. 2005; Mahler 1999, 712). 
From this perspective, since the international courier trade is predicated on long-distance travel, substantial risk, investment, and money making —as well as distribution of cash and a variety of commodities—-women's involvement would be anomalous were it not for their presumed advantages in cultivating social ties. The traditional gender relations lens therefore suggests that social networks are most important to a successful courier business and that women are favored in building such networks given traditional gender traits and arrangements: Women rarely work outside the home; when they do, it is in highly "feminine" ways. Transnationalism, from this perspective, may thus also help break the patriarchy of Salvadoran communities by affording women greater mobility (Gammage 2003; Gammage et al. 2005, 65-66; Mahler 1999). Recent feminist scholarship on globalization, however, challenges such accounts, which “[depict] women and femininity as rooted, traditional, and charged with maintaining domestic continuity in the face of flux and instability caused by global movements that, explicitly or not, embody a quality of masculinity” (Freeman 2001, 1017). By contrast, rather than globalization suddenly pushing women into "otherwise masculine realms of travel, migration, and labor," many women’s labor and physical mobility—past and present, help shape global processes, “even if in small ways” (Freeman 2001, 1017-18, 1014; see also Williams and Baláz 2002, 534). A variation of the assumption that women engage in travel, migration, or labor only as a response to crisis (or globalization) is the tendency to portray gender relations in the Global South as traditional compared with those in the Global North, which scholars such as Chua et al. (2000, 827), Barrow (1993), Cupples (2004), Safa (1995), and Momsen (1995) have challenged. My work further challenges these assumptions in Central America and demonstrates that even in the region that scholars have studied within El Salvador, there is substantial variation in gender relations: While some parts of the northeast are regarded as the "Siberia of El Salvador" 
(MacDonald and Gatehouse 1995, 148), in many others, women command substantial resources and are extensively involved in commerce (Dalton 1987 [1995], Mintz 1971; Thomson 1986; White 1973). During the war (1979-1992), many women headed cooperatives, village councils, rural unions, and revolutionary base communities in rebel-controlled zones within the area (MacDonald and Gatehouse 1995; Thomson 1986). Women also regularly worked as combatants, commanders, engineers, workshop owners and administrators, and medical staff (Carter et al. 1989; MacDonald and Gatehouse 1995; Thomson 1986). More broadly, many women have engaged in paid wage labor, worked as traders, and established their own businesses — traveling and taking substantial risks to succeed (Mintz 1971; White 1973).

Instead of merely being excluded from or manipulated by global processes, many women in the Global South—including, I argue, El Salvador—have expanded the realm of their activities to help shape variable forms of global capitalism (Freeman 2001). This is clearly reflected in research on women transnational traders across the world, though especially by research on higglers in Barbados (Freeman 2000; 2001), women shuttle traders in the Former Soviet Union (FSU) (Mukhina 2009; Yukseker 2004), and rebidantes in Cape Verde (Marques et al. 2001). How do viajeras' experiences compare with their global counterparts? What light can they shed on the variability of contemporary global capitalism?

Women's largely unregulated cross-border shuttle trade in the FSU links markets there with those in the Middle East, Africa, South and Southeast Asia. Istanbul, where tourists from Eastern Europe, Northern Africa, and the Persian Gulf shop, serves as a major hub. Many women shuttle traders are from Slavic republics but live in Russia, where they developed their businesses from the secondary economy—obtaining and distributing consumer goods when the state sector ceased providing goods, services, and jobs in the 1970s and 1980s. These shuttle 
traders have brought billions of dollars worth of foreign currency into Russia, and helped create new markets (Mukhina 2009; Yukseker 2004).

Shuttle traders' regular but largely unregulated cross border trade is more informal than viajeras' work: Shuttle traders tend to cross relatively porous borders using ground transportation and often avoid taxes and customs inspections (though they may pay bribes) (Yukseker 2004; see also Gauthier 2012 on women "ant traders” in Mexico). Shuttlers also work with shopkeepers and market stall owners, engage with multi-ethnic trade networks, and may come into contact with criminal networks and large smuggling operations, including some involved in sex tourism and trafficking (Yukseker 2004). Viajeras, by contrast, engage in long distance air travel across highly regulated international borders and regularly undergo customs inspections. They are also more autonomous than FSU shuttle traders and many own their own stores (eliminating intermediaries); they avoid bazaars or marketplaces, opting instead to deliver goods to clients' homes or to distribute and sell goods from their own stores. Viajeras are embedded almost exclusively in co-ethnic networks (Landolt 2001; Landolt et al. 1999) and, unlike some the of the “uprooted” North African shuttle traders (though these are predominantly men) (Peraldi 2005), the most successful viajeras in my case study were those who could draw most extensively on resources accumulated in El Salvador. Finally, although viajeras do not bring additional foreign currency into El Salvador (the dollar is the national currency) as the shuttle traders do for Russia, they used to; in fact, part of the reason why the government purportedly adopted that dollar as its national currency was to control inflation aggravated by Salvadorans exchanging hundreds of millions of dollars in migrant remittances each year (Garni and Weyher Forthcoming).

By contrast, many viajeras' experiences are closely related to those of Cape Verdean rebidantes (Marques et al. 2001). According to Marques et al. (2001, 290), "the dominance of 
long-distance trade by women seems to be a consequence of historical and cultural specificities allowing those already involved in petty trade to take advantage of available opportunities to expand their activities" (290). Rebidantes conduct long distance air travel, negotiating "severe control by state agents" as they transport goods, letters, and remittances between Cape Verdeans scattered across "three Atlantic continents" (Marques et al 2001, 288, 286). Both rebidantes and viajeras tend to focus on economic goals in conducting their business, and they minimize risk through self-reliance (though they rely on community support) (see also Freeman 2001, 1019). They also both serve as "financial mediators who facilitate transfers between formal and informal sectors” (Marques et al 2001, 287). Finally, both the viajeras examined here and the Cape Verdean women traders that Marques et al. $(2001,285)$ studied engage in international trade to—at least in part—-"escape the...fate of migrating to make a living," as few alternatives for earning an adequate income exist in either Cape Verde or El Salvador. This is somewhat distinctive from Barbadian higglers and Ecuadorian direct sellers who emphasize a sense of pleasure related to their work, though the former may have greater access to salaried employment than Ecuadorian direct sellers do (Freeman 2000; Masi de Casanova 2011).

In sum, many women in Barbados have translated histories of country higglering into transnational higglering while women in Cape Verde have translated histories of working as agricultural traders and business owners into international courier businesses. The viajeras I studied draw on histories of trading goods produced largely on household owned lands to launch similar businesses—and they create opportunities for some local residents to produce and sell goods, as well. My research thus contributes to findings which suggest that women are not "merely" gendered subjects in global factories or consumers in global outposts—all manipulated by multinational capital (un-gendered macro processes versus gendered micro processes) 
(Freeman 2001). Instead, higglers, rebidantes, and viajeras help to (re)define globalization (see also Freeman 2001). Studying how they do so sheds light on local mechanisms for combating inequality and promoting development.

\section{Case Selection and Methods}

Given that 60 percent or more of El Salvador's couriers come from just four departments (similar to large counties) in eastern El Salvador (Abarca 2004a, b; Andrade Eekhoff and SilvaAvalos 2003, 27; Gammage 2003, 12; Gammage et al. 2005)—and despite similar patterns of migration from and remitting to western El Salvador (UNDP 2005)_I focus on women who launch courier businesses from a high-migration eastern community to learn how they do it. This, however, requires nominally addressing why couriers overwhelmingly originate in the east, and how couriers' experiences vary according to whether they launch businesses from the United States or El Salvador. To do so, I draw on comparative work that I conducted in a high migration western community that lacks couriers and relies instead on banks and wire or parcel services (e.g., Gigante Express, Urgente Express).

I spent seven months in El Salvador collecting data from two towns with similar populations, amenities, and histories of migration but differing pre-existing land tenure patterns and modes of receiving remittances. ${ }^{6}$ The first site, Yucuaiquín, is located in northern La Unión, in an area considered to be more conservative than more northern portions of the department (MacDonald and Gatehouse 1995; Thomson 1986). The second community, Masahuat, is located in western El Salvador (Santa Ana). Up until the 1970s, Yucuaiquenses engaged in a variety of economic activities and tended to acquire land and expand its production. According to officials at the mayor's office, 75 percent of Yucuaiquenses owned their own arable land

\footnotetext{
${ }^{6}$ Both towns are reachable via one-hour bus rides along long dirt roads from regional cities.
} 
through the 1970s (though many households have since sold land to absentee landowners to raise capital for other businesses — today, 28 percent of households own their own land (Garni 2013)). Patterns in Masahuat are reversed, with most residents living as sharecroppers on regional haciendas and buying or renting land only with the onset of war and mass migration (and the legal right to do so) in the 1980s. In the late 1970s, about 9 percent of Masahueño households owned their own arable land; today, 22 percent do, and many more rent land to farm for their subsistence (Garni 2013).

Yucuaiquín has nine couriers: seven women and two men. I interviewed every courier in Yucuaiquín, observed one preparing for trip to the United States, and met another in Boston to observe his business there. I also interviewed many of the couriers' clients, several community leaders, youth, and elders. I gained access to couriers by presenting myself as a social science scholar researching migration and development in El Salvador, which was my larger project aim. In the process of conducting interviews via a random sampling technique to generate basic descriptive statistics on land tenure patterns, land use, primary household occupation, and migratory history, I spent time in every neighborhood and with a variety of households. I used official maps to number households and a random number generator to select a 15 percent sample, yielding 40 household interviews in Yucuaiquín and 23 in Masahuat. In total, I conducted 102 interviews in El Salvador and another 16 with emigrants in the United States.

Having access to all of Yucuaiquín’s active couriers was unique. It enabled me to examine how viajeras were able to launch their businesses. While I focus on couriers in what follows, I also draw on interview data from non-couriers (using pseudonyms for all informants). Every testimony is analyzed in light of the data collected for my larger research project. Comparative data from Masahuat serve as a backdrop. 


\section{VIAJERAS’ WORK IN HISTORICAL PERSPECTIVE}

In El Salvador, “life led in the countryside varies according to one’s holdings—or lack of them - in land, and according to the use made of the land in the area where one lives” (White 1973, 139). It also varies according women's access to land: To the extent that women in eastern El Salvador had access to household land and its produce, women's emergence as viajeras in Yucuaiquín may be far more consistent with their local work histories than previous work suggests. They may also have had a significant impact on men's abilities to launch courier businesses, as well. This is because when women in the Global South possess land rights (i.e., they own, co-own, or (co)control land), their households are significantly more productive than they otherwise would be (Baranyi et al. 2004, 49; Deere and Leon 2003; Thomson 1986). Women typically invest more household resources in human capital formation (particularly among youth), promote more diversified household income-generating activities, and generate more non-farm income than men generally do (Moghadam 1999). Raising household income and productivity also generates resources needed for additional business formation, and keeps money circulating (Roberts 1982). Variability in land tenure patterns between communities may help to explain variations in findings across studies on viajeras (and the presence and absence of couriers in the eastern versus western towns that I studied).

In what follows, I examine how women’s historical access to land and labor in Yucuaiquín informed their work in commerce-locally and trans-nationally. All of Yucuaiquín’s viajeras come from landowning families. Several viajeras (and women more generally in Yucuaiquín) also marketed produce and/or handicrafts connected to household production of land, and all of the viajeras own local businesses beyond — and often prior to — their courier work. In addition to explaining how landownership is connected to regional and transnational 
trade, I explore the challenges viajeras face, as well as the strategies they employ to persist in or expand their businesses. This entails analyzing why and how viajeras pursue work as couriersnamely, to expand existing businesses and make more money. I also examine men’s and women's experiences of the social aspects of the courier trade, which vary and challenge several of the arguments presented by the traditional gender relations lens.

\section{Land, Labor, and Commerce}

In El Salvador, export agriculture has long been the cornerstone of Salvadoran politics, society, and economy. "From cocoa, to indigo, to coffee, export agriculture has been the primary determinant of agrarian structure and political economy in El Salvador since the colonial era. The cultivation of the major export crops prescribed the nature of land tenure, the locus of power, and the beneficiaries of profit and prestige in El Salvador” (McReynolds 2002, 136). Recognizing the opportunity to expand their export-oriented cultivation and processing, and controlling the state and national police, many large landowners expelled peasants from the country's most fertile farmland—particularly in the central and western regions, though also along the southern coastal plains (Dunkerley 1988, 182-186; Lauria-Santiago 1999). The result was "a largely polarized system wherein a small number of large commercial estates covering huge swaths of land coexisted with tens of thousands of miniscule peasant plots pressed into a very much smaller area” (Dunkerley 1988, 181).

Yucuaiquenses were among those who retained small plots of land. Many residents took advantage of owning even small parcels by engaging in a variety of income generating activities connected with their farming. This included providing seasonal wage labor on regional haciendas (see also White 1973, 129); investing wages in production of fruits, vegetables, and grains on their own lands (e.g., citrus, melon, avocado, mango, chiles, beans, corn, sorghum); raising cattle 
on their own land (see also White 1973, 139); marketing farm goods and handicrafts both locally and regionally; and investing in small shops and stores to serve other residents engaged in these same activities. Although women cultivated their own fields less than men did, they migrated to perform wage labor on regional haciendas (constituting nearly $40 \%$ of the seasonal wage labor force, with many migrating from eastern and northern departments such as La Unión and Morazán (Thomson 1986, 15; White 1973, 120, 129)). Elena (born in 1949), who recalls sleeping on the ground at night on haciendas and feeling intensely cold, argued: "Here in El Salvador the big rich guys cultivated...cotton, coffee, beans, and sugar cane...[The poor] would go to work [for them], and many people who didn't have a place to live, lived on what they earned, and they bought [land and livestock]...And because the great majority of people had their own livestock, they had everything.” According to Salvador (born in 1956), the hacendados, or hacienda owners, paid very low wages—about 50 cents per 100 pounds harvested. Nonetheless, many people, women included, engaged in such work and used their wages to buy land and capitalize local businesses:

People spent a month there [on the hacienda]. Then in June, July they would plant their own land. They had their animals to tend. Pigs. Then in December, people would go back to the haciendas. The cotton producing haciendas, [and] sugar cane, on the coast. People here, when they grew up, they went to cut, when the harvest was ready. To buy their land. To buy the basics. Their uniform [for school]. To buy their shoes. Their clothes... One girl who had work with the others there, today she's in Houston, shewith just her earnings from picking cotton—bought land and built a house. People did it! That so many Yucuaiquenses produced fruit and maintained their own livestock is consistent with the fact that so many owned their own land: Fruit trees take a long time to mature, so 
typically only farmers who own their own land can invest in raising fruit (see also Barrow 1993), and landowners often graze their cattle on the shorn stalks of renters' harvests: Renters lease land seasonally and must forfeit the remnants of whatever they plant at the end of the season.

According to White (1973, 140, 150), half of the fruit sold in urban and regional markets throughout El Salvador was produced domestically, and most of the people selling fruit, grains, and handicrafts were women: "Fruit and vegetables locally produced may reach the urban marketplaces more directly [than via wholesalers], either being brought to the main stallholders by the producers themselves (or rather their wives, since this kind of trading is women's work); or else the stallholders or market women buy them in the local markets of the rural areas around the capital” or other cities (see also Thomson 1986). This is highly significant: Many women in El Salvador who lacked access to land took loans to buy goods from other producers. They would then have to sell the goods they bought and pay interest on the loans. Most of these vendors struggled to make a subsistence wage. By contrast, most women in Yucuaiquín could avoid such loans and reap more profit (Dalton 1979 [1995]; White 1973). They produced and traded their own goods, and sometimes even sold their goods to other women traders:

Maura (born in 1964): We would sell it [what we harvested from family owned land]. We would go from house to house, or if not, a woman would buy everything and take it, and she would sell it...Because there was a time when we would harvest many, many...like 25 dozen melons! So she would carry them on horseback. She would take all of it there [to San Miguel, the third largest city in the country, roughly an hour's drive on a steep dirt road that is difficult to navigate]... She took it to sell and distribute. Recalling that his mother sold produce in urban markets (or to miners in a nearby town), Pablo (born in 1930) was among those explaining how it worked: 
The bus that used to take her was called La Jocorreña...And to travel in that bus—it took everything! Corn, animals, and chickens, pigs_-people would put them up on the roof....At first, my dad tells me that they traveled—my mom traveled a lot—with a basket to San Miguel. Many people, not just her. Or on horseback. They would go to mines that were over in Divisadero, on this side by Jocorro, Santa Rosa, to sell fruit. Bread. Many things. They also took things to San Miguel...on average one day [a week], to sell watermelon, melons. Mango. All of that. Sometimes they would go with ox-drawn carts. They even went with candles, gas candles!

All of Yucuaiquín’s viajeras had prior experience selling goods produced on household owned land or in their homes. Providing a prominent example, Alejandra (born in 1949), a longtime viajera, became animated as she told me about learning to sell goods by working alongside her mother and grandmother. As she grew older, she arranged with her father to sell papayas from their land, and she invested the earnings in launching other small businesses. She now owns a pupusería [a small restaurant specializing in pupusas—a Salvadoran dish consisting of thick corn pancakes stuffed with beans, cheese, sausage, and local spices], a clothing/shoe and school supply store, and a courier business, all based in Yucuaiquín:

I have always loved commerce—being a businesswoman. Sometimes my mom would go out and sell and ever since I was a little girl I loved the business. And that's how I started—young, really young, selling things. And then, little by little, it grew, and that is how it's been my whole life. I would walk around with baskets selling quesadillas made from corn. I would sell boxes full, saying "good morning, would you like to buy a quesadilla?” And gradually I would sell everything. I always liked it... Later, I worked with my uncle in San Salvador for six years. He had a business, a store, and I would help 
him and even run it when he went out. I liked it and I always said to myself that one day I would have the opportunity to have a store, I would! So I got started by selling papaya from land that my family owned and I made eight thousand dollars [colones—about one thousand U.S. dollars]. Every day I went to San Miguel to sell my papayas. In the morning I would harvest them and in the afternoon I sold them. And with the money I made, I opened this store, and that is how this all started.

In addition to marketing produce, many women in Yucuaiquín (and several men) also made goods from locally produced materials and sold them regionally. These goods included prepared food, mats, hats, and cookware. Beatriz (born in 1937), who started her courier business during the war in 1988, comes from a landowning family, as does her daughter-in-law, Dominga (born in 1972), who inherited and now runs Beatriz's courier business. Beatriz helped her family to sell produce from their farm when she was a young girl. She and several of her peers (women) also made mats, earthenware, and other goods for local and urban markets (see also Thomson 1986; White 1973, 140, 146, 147). Many people, Beatriz says, also contracted with a factory in San Miguel to provide the materials needed to make hats (and sometimes whicker furniture): I tell you that here there was a whole job market to make luxurious pots, pans, comales [a wide, shallow pan much like a wok that Salvadorans use to make fresh corn tortillas], woven mats, hats, braids. We would make them by the dozens and we would sell them. Mrs. Hernández [Beatriz’s elderly neighbor] would take dozens of the braided palms to the Port of Cojutepeque where there were factories that made hats. And now there are no factories!...So braided palm is worthless now—no one buys them anymore. With the decline of the local patrimonio (local specialization in handicrafts), Beatriz married a schoolteacher and opened a diner in her house. Having acquired a tourist visa in the 1970s, "all 
of her girlfriends urged her to travel.” She decided to leave her diner in the hands of several women she hired to help her, and experimented—carrying goods back and forth from Dallas. Alejandra (born in 1949), part of a second mother-in-law/daughter-in-law courier team, noticed several people like Beatriz getting tourist visas and working as couriers: "I got the idea [to travel] from another friend who went to apply for a visa and go on a sightseeing trip. She saw the movement from other couriers and came back to tell me about it. So I told her [my mother-inlaw], let’s go get a visa!” Alejandra and her mother-in law traveled together to parts of Maine for nearly a decade before separating to travel independently (the mother-in-law has now retired). From Producers and Traders to Couriers

In Yucuaiquín, much of the commerce that women have historically performed is connected with household ownership of land, which facilitated the launching of other, related enterprises - courier services currently being the apex of such entrepreneurship. With the exception of Maribel (born in 1970) who launched her courier business before opening several relatively large businesses in Yucuaiquín, each viajera first founded a restaurant, beauty salon, and/or retail shop, and then expanded into providing courier services. In contrast, neither of the two men owned a shop or business in Yucuaiquín (aside from the courier business). However, Mario (born in 1952) served as mayor for a number of years. Fidel (born in 1947) and his wife sold grains locally and in San Miguel, but his wife worked as a school teacher for most of her life and now collects a pension that is roughly equivalent to Fidel's courier earnings.

Maribel and Mario represent the only exceptions to the pattern of landownership facilitating additional business formation and courier work. Maribel came from a landowning family in Yucuaiquín and likely could have followed the same route the other viajeras did, but she married a man who migrated to the United States and decided to follow him. Maribel 
worked for years cleaning airplanes and selling gold (independently) in the United States before using U.S. residency status to become a viajera and open other businesses in Yucuaiquín. Mario, by contrast, came from a landless family. His father died when he was very young, and his mother, though she remarried, raised Mario alone, using her earnings from doing laundry and ironing for other local families. Many women from landless families in Yucuaiquín provided domestic services to landed families, including washing, cleaning, cooking, and childcare. Men from landless families typically worked as wage laborers for local landowners (sowing and harvesting crops, preparing land for cultivation, tending to livestock, and the like). Mario migrated to the United States and worked for many years as a mechanic before becoming a courier (at which point he moved back to Yucuaiquín), in 1991. He obtained residency through amnesty and used his U.S.-based savings to buy plane tickets and build a house in Yucuaiquín. By contrast, the two people working as couriers when Mario began were heirs to the largest landowning family in Yucuaiquín (both have retired). According to a current viajera,

Nuria (born in 1952): The first and most important ones were the Vásquez family and Juan's wife. Because you had to get in line to send anything—-there were no couriers. Before, people were more ignorant about applying for visas. As people would say, 'only those who have a ton of money'—and that just wasn't the case [you didn't have to have a ton of money].

What you do need is proof of employment, savings, land, and other roots to El Salvador. According to Fidel and his wife, Erlinda, you need:

$$
\text { “\$4,000 ..." }
$$


(Erlinda interrupts) “\$4000. It’s like a fund for anything that happens. You have to work. And before, when he wasn't a courier—well, when he wasn't declaring as if he were a courier, but rather as a tourist, he had to carry..."7

(Fidel interrupts) “If I didn’t have $\$ 1000$, they wouldn’t let me enter [the United States]. They thought I might be going there to live. As if I was...”

(Erlinda interrupts) "To prove that he was only passing through.”

"Yeah, I had to prove I was just visiting and that I had enough money to pay for a hotel and to eat for a week before returning [to El Salvador].”

In Masahuat, by contrast, residents have largely been unsuccessful in obtaining visas or launching competitive local businesses. Despite similar patterns of migration to and remitting from the United States, Yucuaiquín has three times as many businesses as Masahuat, and while 28 of the retail businesses in Yucuaiquín were launched with investments in excess of \$6,000, there are no such businesses in Masahuat (Garni 2013). A long history of sharecropping followed by national agricultural decline has left many Masahueños without the kinds of assets that Yucuaiquenses have to launch businesses or demonstrate strong ties to El Salvador, obtain visas, and travel. Women in Masahuat do operate local shops and businesses, but there are fewer shops or stores to run. Women also sell food in the town square or peddle goods from door to door. However, men who own pickup trucks and carry merchandise from local cities tend to outcompete local women vendors (women usually travel on buses to buy merchandise in cities-

${ }^{7}$ Couriers must register with the Ministry of Finance (Customs Division) by passing a test on customs and tax laws, showing proof of Salvadoran citizenship and savings of at least $\$ 5,280.60$ (up from $\$ 4000$ in 2007), and providing three means by which the government can contact them. Officials verify registration at the airport (Ministerio de Hacienda 2010a,b). 
but clients in town complain that they bring too little and provide inadequate selection). Thus, although women's participation in commerce Masahuat was lower than that in Yucuaiquín, there was also less commerce generally, which helps to account for some of these differences.

In Yucuaiquín, Beatriz used land and business profits to lauch a courier business, earnings from the courier business to buy and sell more land, and profits from both to open a funeral parlor and gift shop featuring locally made goods in her very large and well-appointed house. In the early 1990s, she recognized initial inflation in local land prices (U.S. based migrants began buying lots to build retirement homes). She thus bought extra land and sold it at greatly inflated prices ten years later. Other viajeras have also variably sold and retained landin the latter case often renting it to farmers in adjacent rural hamlets (many of whom receive remittances from relatives working in the United States). While there was initially a lot of money to be made in a short period of time by leveraging land and other business profits to launch couriers businesses, today rising transportation costs mean that even more capital (or credit) may be needed to launch or sustain courier businesses.

Airlines currently pose the greatest threats to viajeras' businesses, and by extension to the local businesses they support:

Dominga: You have to buy the plane ticket...and I am almost always paying \$700, $\$ 740 \ldots$ Then you have to pay for transportation between here and Comalapa [E] Salvador’s international airport, located near San Salvador, about 3.5-4 hours from Yucuaiquín], and then the little bit that you buy to sell. So the earnings are about $\$ 300$ to $\$ 400$. But for me, that’s ok, I guess, because for most employees here, they are earning the minimum [i.e., the minimum wage, which is about $\$ 152$ per month]. Luggage restrictions and rising airfare are the main problem. For example (from my fielnotes): 
Dominga sat down and began sewing the seams of four large duffel bags. She says that she prefers the duffel bags to wheeled suitcases because they are lighter, even though they are more awkward to carry. She drags them through airports and breaks the seams on most of her trips. Wheeled suitcases are "way too heavy" and she wants to save the weight for packages and merchandise. "I want to make as much money as I can," especially "now that there are weight restrictions on the planes and everything has gotten so expensive.” Beatriz chimes in too, saying that she thinks it is harder for Dominga to travel now than it ever was for her: Airlines are imposing more luggage restrictions, Salvadoran custom charge more money for importing goods and cash, transportation costs have risen, and more people are robbing couriers.

Companies that get around the restrictions to which couriers are subject, as, for example, via CAFTA, may be able to sell goods at lower prices to Salvadorans, while still making considerable profits, and eliminate couriers as competition (see Hernández-León 2005 for Mexico). Some couriers have organized to regularize their travel business, as through E1 and E2 business visa allotments (Gammage et al. 2005, 69), but additional strides are necessary.

Since couriers bring remittances directly to Yucuaiquín and recipients tend to spend them locally, storeowners reported that spikes in sales consistently occur just after couriers arrive from the United States. Many store owners offer customers credit in the interim (some even charge interest). In this way, couriers ensure business for other local entrepreneurs. In Mashuat, by contrast, residents must travel to cities to receive remittances, and they often spend the money in those same cities to avoid traveling with cash and putting themselves at risk for being robbed. Viajeras also create jobs locally in Yucuaiquín by hiring other residents to run their subsidiary 
businesses while they are away, to help them with their courier businesses, and to make goods that they sell in the United States. For example (from my observations of Dominga and Beatriz): Dominga called to a man who appeared to be several years older and asked him if he would remove all of the plastic bags with tamales from the refrigerator and dispose of them—or give them away (she was paying him a "few dollars for a few hours of work"). He disappeared into the kitchen. He returned 20 or so minutes later to say that he had given the tamales to a relative. Dominga asked if he had gotten the bags on the bottom shelf, and when he said that he hadn't, he left the room to retrieve and dispose of them. I asked Dominga what was going on and she said that she had decided to buy tamales from "another woman this time so that she could earn something, too.” Dominga wanted to “spread her business around," but now regrets it: She bought $\$ 100$ worth of tamales the night before from a neighbor. When she tasted them early this morning, they were bitter and hard. Dominga was nearly shouting at this point, and told me that she was really angry. I asked if she could get her money back and she said, "not likely.” She would return to her usual supplier, another woman who "charges more but does a better job.” Most of the viajeras buy perishable goods from local vendors to sell in the United States. These providers count on the couriers for business.

We're Going to Make It, You'll See!

When I asked couriers what they liked best about the business, the most common answer involved making money, followed by love of business and adventure. In Fidel's case, he says that he earns as much from working as a couriers as his wife does from her pension. As there has been no viable work in agriculture since the mid 1990s, he would otherwise lack income (when I asked him how he came up with the idea to travel, he said, "hunger!"). Unable to work in the 
United States using tourist visas, and lacking adequate wage labor in El Salvador, most of Yucuaiquín’s couriers rely on the courier businesses as their main source of income. According to Beatriz, "I liked making a lot of money, but that was all I really liked about it [the courier business].” Nonetheless, it wasn’t until a car accident killed her husband and nearly cost her an arm that Beatriz agreed—after her son pleaded with her—-to retire: "I made a few more trips afterward, but my son said that I was going to return to El Salvador without my arm, or with my arm in a suitcase, and he urged me to stop. I took his advice and retired.” Dominga, her daughterin-law, took over Beatriz’s business in 2000: “This business of carrying remittances, that was my mother-in-law's work, but she had an accident and couldn’t continue...So she gave me the business so that I could carry on with it.” Dominga confided in me that her husband was recently laid off from a national telecommunications company, where he had earned $\$ 800$ per month, and she feels that their economic situation is deteriorating. Traveling is hard on her, she says, but she cannot quit, because her in-house salon services (she is also a cosmetologist) only bring in \$2 per haircut, and she often only gets one client a day. If she provides color services, she charges $\$ 10$, but few people ask for this. Dominga says she feels “suffocated” by all of this and has trouble sleeping at night. She worries that there is no future in Yucuaiquín for her 15year-old son, especially since her husband remains unemployed.

For many viajeras, making money is connected with supporting family and being willing to do things that their husbands or partners are unwilling to do. This challenges "traditionalist" expectations that the courier business, involving risk, would tend to exclude women:

Maribel: I said to my husband, "do you see? Do you see that things pan out because they have to?” At least that's how I am, I always have a positive attitude and I say, "I am going to come out ahead. It has to work out,” and just like that, it works out for me! 
When he says, “you are not going to get any remittances to carry,” I say, "yes, I will, you'll see.” My husband, well, let’s just say that he’s a bit more cynical, [he'll say] "I don't think that such and such is going to work out, but I encourage and support you,” and that is all he has ever done for the business...I tell him that I can’t guarantee to him that an idea will pay off, ...but one has to just risk it, and it will pay off or it won’t. Similarly, after telling me that she made $\$ 50,000$ in eight years as a viajera, Leila (born in 1948) explained, 'they gave me the visa, and I told my husband, 'I'm going to travel.' I noticed that many people were traveling and I said to myself, ‘why shouldn’t I do that, too?’ My husband didn’t really like that very much because he doesn’t really like it when I leave the house.”

Author: Why?

Leila: He’s been really—well, um, he’s a homebody...You won’t ever really see him out on the street at all, except when he goes to church, or to visit his mother, or on an errandmaybe to the countryside. And when he's out there he blushes a lot. And, in all of the time that we have been married, in all of this time, I have never seen him with a bottle [of alcohol] in his hand. So, you know, he’s really a homebody.

Author: And you?

Leila: Well, I am less of a homebody. So I said, “I’m going to travel.” I did! Because, "whatever happens, we are going to make it, we are going to get ahead." In Nuria's experience:

Nuria: So later when my husband came, he comes to see his father, he doesn't like the [courier] business, and he tells me, “if I lose anything, I won't take responsibility.” My husband, you see, he is a bit fearful. Because men are afraid. First, my husband is afraid of airplanes. Second, he does not know how to manage well...So he prefers to 
work in construction. Around here, with my family, it’s always the women who [run the businesses]...and the husbands have to go work there [in the United States] in construction or in a factory.

Interestingly, more men than women do migrate to the United States. The ratio of men to women leaving El Salvador—initially balanced, has tipped in favor of men: From 1971 through 1980, for every 100 women who left El Salvador, an average of 106 men migrated (UNDP 2005, 39). In the 1980s through the mid 1990s, the ratio shifted slightly more in favor of men: for every 100 women, 113 men migrated (UNDP 2005, 39; SIEMCA/IOM 2004). This pattern held until 1998, when suddenly for every 100 women, 245 men migrated (UNDP 2005; SIEMCA/OIM 2004). In 2000 this pattern reached a peak, with more than 500 men migrating for every 100 women. As of 2004, for every 100 women who migrated, 318 men did (UNDP 2005, 39). Further research is needed to explain this sudden shift.

Whereas most of the viajeras emphasized making money as a primary motivation for launching the business, Viviana (born in 1974) connected her courier work with a passion for business and adventure, as well with a desire to make money and be independent:

Viviana: We [my husband and I] wanted to prosper more, because the truth is, as long as God permits it, you have to take advantage of being able to do so...Y You have to do this alone sometimes too because we navigate life alone and it is important not to be dependent on someone else...So the truth is that I got a visa [in 1999] and I love to travel, even in spite of all the work I have-and to have some fun in other places. And you can go and visit family or friends, and I liked that.

Author: So the first time you traveled, you did it for fun?

Viviana: No, no, no. I went to get to know the United States. I loved it. I loved it and I loved 
the people, too, and there were things that I had never seen. For example, the languages, you know what I mean? One feels deafened by not being able to [speak or understand], because for years I couldn’t understand them. But I kept on learning.

Viviana's experience is consistent with what Freeman (2000) found among suitcase traders in Barbados, many of whom regarded their work as enjoyable (see also Masi de Casanova 2011). Previous scholars have argued that a gender-based ability to cultivate social ties is crucial to the courier business, and that women are favored in this endeavor (e.g., Gammage et al. 2005; Mahler 1999). I also found that social ties matter, but both men and women in Yucuaiquín were concerned with them, in slightly different ways. Most women relied on their non-courier businesses to sustain or develop ties with clients. Mario, by contrast, relied on sports. In Yucuaiquín, there is an active all-women's softball league (the team competes with other teams from La Unión), but historically men have been more active in playing soccer, and have carried these activities over into their lives in the United States, often gathering in city or municipal parks to play and socialize:

Author: How did you decide to become a courier?

Mario: Well, I was in Boston, and I have always been involved in sports. I had been working there for almost 11 years and on the weekends I helped mentor a youth group. That's how I got to thinking —analyzing. There were only two people working as couriers...And I started to think, "my children have already grown up, I'm going to travel!” I told my brothers in New York about the idea and we started making noise [letting people know].

Social ties remained significant to Mario as he launched his business: "You know, the nicest thing [about this business] is that sometimes you are able to communicate with everyone, that is 
what I like. To share, like when you get to come here and you come here to talk [with your clients]. I really love that a lot.” To the other extreme, Leila claimed that client relations were what she liked least about the business, as she felt that gossip among migrants from El Salvador to the United States created cliques that she was wary of having to navigate (see also Menjívar 2011). Leila responded to these challenges by demonstrating "professionalism" in her services, never favoring one client over another and avoiding gossip. This runs counter to Gammage’s (2003) and Gammage et al.’s (2005) findings, which suggest that participating in gossip appeared to help women couriers secure business. Crucially, this was not isolated to only one of the viajeras that I interviewed. Dominga's reaction was similar to Leila's, and I observed it in action (and operating in the reverse direction—-from El Salvador to the United States) as I watched Dominga prepare for a trip. Whenever a client delivered a package, Beatriz left the room and Dominga kept her interactions to a minimum. For example (based on my fieldnotes):

Beatriz slipped away each time someone came to deliver a package...When a middleaged woman wearing a long skirt and mud-stained t-shirt entered the courtyard holding a square package, maybe 12 x12 inches, Dominga set aside the small round cooler she was holding and looked up at the woman. Without saying anything, Dominga reached out to take the package. Also wordlessly, the client handed the package to Dominga, and Dominga asked if it was “the usual?" Client: "Yes, how much will it cost?” Dominga: “\$25 dollars.” The client nodded. Dominga stacked the woman’s package on the already full table and turned her attention back to the original cooler. The client left quietly, and Dominga told me that the package contained tamales. Beatriz returned and saw me watching Dominga unwrap another cooler. "Sometimes people hide gold in the cheese or the cream,” she explained, forcing them to open, inspect, and re-seal every container. 
Dominga had apparently worked several times with the clients who delivered packages to her, as she knew what each one contained without seeing the contents or being told what was inside. Nonetheless, her conversations with other clients were equally sparse. Also, it is clear from this interaction and all of my interviews that clients must not only trust couriers, but couriers must also trust their clients. If a courier is caught carrying forbidden goods, she can be fined thousands of dollars and lose her licenses. Maintaining a certain distance, perhaps so that no one feels offended that a courier is opening, searching, and re-sealing his or her packages, appears to be part of viajeras' strategy in successfully navigating the many risks asssociated with the business. This is not to say that client relations are insignificant to viajeras: to the contrary, being reliable and professional is how viajeras in Yucuaiquín seek to secure their clientele. (Mario and his nephew were also quite busy when clients delivered packages, but Mario smiled more and exchanged more pleasantries. It is possible that couriers visit more extensively with clients when they deliver goods to their homes, though many couriers hire other people to do this for them.)

I also noticed that men and women may handle the declaration or customs process in El Salvador slightly differently. Most of the couriers I interviewed said that they usually carry $\$ 10,000$ or less in cash remittances per trip, though they must declare amounts in excess of $\$ 10,000$. One male courier openly claimed to declare an average of $\$ 40,000$ on each trip, but another woman said, "no one, NO ONE, declared the money.” When I asked how officials were unaware of the cash, she responded, "oh they know that we're carrying money. But they don’t ask how much. But once, they asked me to open my wallet, and I said, 'what for?' 'It's just that, we need to check.' 'No,' I said, 'not even my husband goes around looking in my wallet, why would I let you?'” According to this courier, she was thus allowed to pass carrying thousands of dollars "hidden" in her wallet. In admonishing a male customs official for contemplating 
searching her private belongings, this viajera apparently invoked a gender norm to evade detection. Men may employ different gender based strategies to negotiate with authorities. My data do not allow me to address this, but these patterns deserve more attention in future work.

\section{DISCUSSION}

Distinguishing the different routes that couriers take in launching their businesses generates important questions about variability in the circumstances that men and women face. Couriers with fewer resources in El Salvador may be more likely to launch businesses from the United States where they can obtain adequate wage labor, as was the case for Mario, who lacked land and assets in El Salvador. Viajeras in Yucuaiquín, by contrast, drew on connections to land and commerce to expand their historical roles in trade—now transnational in form.

For couriers wishing to launch businesses from El Salvador, versus the United States, the "legal, financial, and social wherewithal" to travel is, contra the traditional gender relations lens, perhaps most significant. Such wherewithal is connected to gender in Yucuaiquín, though not in the ways that these scholars might anticipate: Since Yucuaiquense women have a long history of working as traders, and migrating to haciendas to perform wage labor, their present roles as couriers are largely consistent with their personal biographies. It also connects with land ownership patterns in Yucuaiquín. Further, rather than men’s work in the courier trade relating to men's supposed proclivities for risk-taking and financial gain, while women participate purportedly due to social ties, I found that women in Yucuaiquín draw on business experience and regard themselves as the primary risk takers and money makers. Contradicting gender stereotypes, viajeras in Yucuaiquín identified social ties as a mechanism of exclusion (even as they remained crucial to their business) (see also Menjívar 2011), while men seemed to enjoy the social aspects of the trade. Research on gendered organizations in the United States similarly 
suggests that social networks can exclude women from promotion while creating advantages for men (Britton and Logan 2008; Williams et al. 2012). Rather than personal traits explaining gender based inequality, organizations reflect and reinforce social structures that produce gender inequality (and personal experiences of it).

Although Yucuaiquín’s viajeras drew on a history of small-scale land-ownership and trade to launch businesses, their historical advantages may be waning. Whereas in the past Yucuaiquense trading was firmly rooted in local agricultural and handicraft production, today it is based on migration and imports. Opportunities to make goods to sell to Salvadorans in the United States are limited, and the more expensive it becomes for couriers to deliver goods, and the more that international wholesalers import goods in bulk to Salvadorans in the United States and El Salvador, the less money that couriers will make. Lacking alternative wage labor opportunities in El Salvador, like many Barbadian suitcase traders have, Salvadorans may be forced to find new or more limited ways of competing (or find work in the United States). However, people receiving remittances will likely continue buying consumer products in El Salvador. To persist in their trade, couriers need greater restrictions on large-scale imports, but greater freedom in their own ability to import.

Viajeras provide an alternative to elite dominated banking and increase the likelihood that cash will circulate locally in El Salvador. Rather than controlling the agro-export sector—which they quashed via trade liberalization (CAFTA) and dollarization in the 1990s and early 2000sthe elite today instead control banking, communications, and transportation (Madrid 2009; Segovia 2005). In a neoliberal and high migration era, controlling such sectors enables the elite to continue capitalizing on the alienation of the majority of the Salvadoran population, though in new ways: Unemployed in El Salvador, many Salvadorans migrate to work in the United States 
(or Canada). To assist their un- or under-employed relatives in El Salvador, they send remittances. While Gammage (2006) claims that this represents a “development policy,” in which the elite "export people” as commodities, several scholars have challenged this view, arguing that people export themselves (Garni and Weyher Forthcoming; Hernandez and Coutin 2006). In other words, the elite only produce the conditions that make people feel the need to migrate; they do not organize or pay for migration, as the commodity notion suggests (Garni and Weyher Forthcoming). Instead, Salvadorans pay their own way to the United States and support themselves before, during, and after their migration. Salvadorans thus themselves assume the costs of their own (re)production, and send money back to El Salvador. When they or their loved ones spend money on banking, transportation, or communications — as many do — the elite profit from this cycle of alienation and migration. Rather than investing these profits in domestic production that would employ erstwhile migrants, the elite instead expand their investments in other high-migration countries, perpetuating the process (Garni and Weyher Forthcoming; Segovia 2005). Salvadoran women's efforts to generate additional sources of income are crucial for Salvadorans’ ongoing efforts to combat poverty and promote local development in a new era, and their experiences illustrate how women’s labor and physical mobility are constitutive of, and not merely a reaction to, globalization in its various forms. 


\section{REFERENCES}

Abarca, Bianca. 2004a. “A Media Jornada.” La Prensa Grafica, Enfoques. February 1, 2.

Abarca, Bianca. 2004b. “Los pequeños se volvieron gigantes.” La Prensa Grafica, Enfoques. February 1, 1.

Andrade Eekhoff, Katherine and Claudia Maria Silva-Avalos. 2003. “Globalization of the periphery: The challenges of transnational migration for local development in Central America.” San Salvador: Facultad Latinoamericana de Ciencias Sociales (FLACSO).

Anner, Mark S. 2011 Solidarity Transformed: Labor Responses to Globalization and Crisis in Latin America. Ithaca, NY: ILR Press.

Baranyi, Stephen and Carmen Diana Deere, M. Morales. 2004. Land \& Development in Latin America: Openings for Policy Research. Ottawa: The North-South Institute.

Barrow, Christine. 1993. "Small farm food production \& gender in Barbados,” In Janet Momsen (ed.), Women and Social Change in the Caribbean: A Pan-Caribbean Perspective: pp. 181194. Bloomington: Indiana University Press.

Burton, Barbara and Sarah Gammage. 2009. "El Envio: Remittances, Rights and Associations among Central American Immigrants in Greater Washington DC,” In K. Fine-Dare and S.L. Rubenstein (eds.), Border Crossings: Transnational Americanist Anthropology: pp. 211-229. Lincoln: University of Nebraska Press.

Britton, Dana and Laura Logan. 2008. "Gendered Organizations: Progress and Prospects." Sociology Compass 2:1: 107-121.

Carter, Brenda and Kevin Insko, David Loeb, Marlene Tobias. 1989. A Dream Compels Us: Voices of Salvadoran Women. Boston, MA: South End Press.

Chua, Peter and Kum-Kum Bhavnani, John Foran. 2000. "Women, culture, development: a new 
paradigm for development studies?” Ethnic and Racial Studies 23: 820-841.

Cupples, Julie. 2004. "Rural Development in El Hatillo, Nicaragua: Gender, Neoliberalism, and Environmental Risk.” Singapore Journal of Tropical Geography 25: 343-357

Dalton, Roque. 1987 [1995]. Miguel Marmol. New York, NY: Curbstone Books.

Deere, Carmen Diana and Magdalena Leon. 2003. “The Gender Asset Gap: Land in Latin America.” World Development 31:6: 925-947.

Dirección General de Estadística y Censos/Census Bureau of El Salvador (DIGESTYC). 2012, 2008. Retrieved June 2, 2012 (http://www.digestyc.gob.sv/).

Dunkerley, James. 1988. Power in the Isthmus: A Political History of Modern Central America. London/New York: Verso.

Equipo Maíz. 2004 ¿Cómo Quedó el TLC? San Salvador: Asociación Equipo Maíz.

Freeman, Carla. 1997. "Reinventing Higglering Across Transnational Zones: Barbadian Women

Juggle the Triple Shift," In Consuelo Lopez Springfield (ed.), Daughters of Caliban:

Caribbean Women in the Twentieth Century: pp. 68-95. Bloomington: Indiana University Press.

Freeman, Carla. 2000. High Tech and High Heels in the Global Economy: Women, Work, and Pink-Collar Identities in the Caribbean. Durham, NC: Duke University Press.

Freeman, Carla. 2001. "Is Local: Global as Feminine: Masculine? Rethinking the Gender of Globalization.” Signs: Journal of Women in Culture and Society 26:4: 1007-1037.

Gammage, Sarah. 2003. "Viajeros y Viajeras en El Salvador: Enlazando Mundos, Estrechando Vínculos.” La Transnacionalización de La Sociedad Centroamericana: Nuevos Retos Planteados a Partir de la Migración Internacional. San Salvador. FLACSO/RR.EE. Gammage, Sarah. 2006. “Exporting People and Recruiting Remittances: A Development 
Strategy for El Salvador?” Latin American Perspectives 33:6: 75-100.

Gammage, Sarah and Alison Paul, Melany Machado, Manuel Benítez. 2005. “Gender, Migration and Transnational Communities, A draft report prepared for the Inter-American Foundation.” Retrieved June 15, 2012 (http://previous.wiego.org/pdf/Gammage-Gender-MigrationTransnational-Communities.pdf.)

Garni, Alisa. 2013. “Land Tenure, Migration, and Development: A Comparative Case Study,” Latin American Research Review 48:1: 133-154.

Garni, Alisa and L. Frank Weyher. Forthcoming. “Dollars, 'Free-Trade,' and Migration: The Combined Forces of Alienation in Post-War El Salvador,” Latin American Perspectives.

Gauthier, Melissa. 2012. "Mexican "ant traders" in the El Paso/Ciudad Juarez border region: Tensions between globalization, securitization and new mobility regimes,” In Gordon Mathews, Gustavo Ribeiro, Carlos Alba Vega (eds.), Globalization from Below: The World's Other Economy: pp. 138-153. New York, NY: Routledge.

Hecht, Susanna B., Susan Kandel, Ileana Gomes, Nelson Cuellar, and Hermán Rosa. 2005 "Globalization, Forest Resurgence, and Environmental Politics in El Salvador." World Development 34:2: 308-323.

Hernández, Ester and Susan Bibler Coutin. 2006. "Remitting subjects: migrants, money, and states.” Economy and Society 35:2: 185-208.

Hernández-León, Ruben. 2005. “The Migration Industry in the Mexico-U.S. Migratory System,” California Center for Population Research On-Line Working Paper Series. Retrieved May 2, 2012 (http://www.ccpr.ucla.edu/ccprwpseries/ccpr_049_05.pdf.)

Lardé y Larín, Jorge. 2000. El Salvador: Historia de sus Pueblos, Villas y Ciudades, Second Edition. San Salvador: Consejo Nacional para la Cultura y el Arte. 
Landolt, Patricia. 2001. "Salvadoran economic transnationalism: Embedded strategies for household maintenance, immigrant incorporation, and entrepreneurial expansion.” Global Networks 1:3: 217-241.

Landolt, Patricia and Lilian Autler, Sonia Baires. 1999. "From Hermano Lejano to Hermano Mayor: The Dialectics of Salvadoran Transnationalism.” Ethnic and Racial Studies 22:2: 290-315.

Lauria Santiago, Aldo. 1999. An Agrarian Republic: Commercial Agriculture and the Politics of Peasant Communities in El Salvador, 1823-1914. Pittsburg, PA: University of Pittsburg Press.

MacDonald, Mandy and Mike Gatehouse. 1995. In the Mountains of Morazán: Portrait of a Returned Refugee Community in El Salvador. London: Latin American Bureau.

Madrid, Cori. 2009. “El Salvador and the Central American Free Trade Agreement: Consolidation of a Transnational Capitalist Class.” Perspectives on Global Development and Technology 8:2: 189-210.

Mahler, Sarah J. 1999. “Engendering Transnational Migration: A Case Study Of Salvadorans.” American Behavioral Scientist 42:4: 690-719.

Marques, M. Margarida, Rui Santos, and Fernanda Araujo. 2001. “Ariadne’s Thread: Cape Verdean Women in Transnational Webs.” Global Networks 1:3: 283-306.

Massey, Doreen. 1994. Space, Place, and Gender. Minneapolis, MN: University of Minnesota Press.

Masi de Casanova, Erynn. 2011. Making Up the Difference: Women, Beauty, and Direct Selling in Ecuador. Austin, TX: University of Texas Press. 
Massiah, Jocelin. 1986. “Work in the Lives of Caribbean Women.” Social and Economic Studies 35:2: $177-240$.

Menjívar, Cecilia. 2011. Enduring Violence: Ladina Women's Lives in Guatemala. Berkeley, CA: University of California Press.

Miller, Jody. 2001. One of the Guys: Girls, Gangs, and Gender. Oxford: Oxford University Press.

Ministerio de Hacienda. 2010a. Direccion General de Aduanas El Salvador. Autorización de Gestores de Encomiendas Persona Natural. Retrieved September 4, 2011 (http://www.aduana.gob.sv/index.php?option=com_content\&task=view\&id=186\&Itemid=34 \&lang=)

Ministerio de Hacienda. 2010b. Direccion General de Aduanas El Salvador: Guia del Viajero. Retrieved September 4, 2011 (www.aduana.gob.sv.)

Mintz, Sidney W. 1971. “Men, Women, and Trade.” Comparative Studies in Society and History 13:3: 247-269.

Moghadam, Valentine. 1999. “Gender and Globalization: Female Labor and Women’s Mobilization.” Journal of World-Systems Research 2: 367-388

Momsen, Janet. “Introduction,” In Janet Momsen (ed.) Women and Social Change in the Caribbean: A Pan Caribbean Perspective pp. 1-12. Bloomington: Indiana University Press.

Mukhina, Irina. 2009. “New Losses, New Opportunities: (Soviet) Women in the Shuttle Trade, 1987-1998.” Journal of Social History 43:2: 341-359.

Peraldi, Michel. 2005. “Algerian Routes: Emancipation, Deterritorialisation and Transnationalism through Suitcase Trade.” History and Anthropology 16:1: 47-61. Pessar, Patricia R. and Sarah J. Mahler. 2003. “Transnational Migration: Bringing Gender In.” 
International Migration Review 37: 812-846.

Roberts, Kenneth D. 1982. “Agrarian Structure and Labor Mobility in Rural Mexico.” Population and Development Review 8:2: 299-322.

Safa, Helen I. 1995. The Myth of the Male Breadwinner: Women and Industrialization in the Caribbean. Boulder, CO: University of Colorado Press.

Segovia, Alexander. 2002. Transformación Estructural y Reforma Económica en El Salvador:

El Funcionamiento Económico de los Noventa y sus Efectos sobre El Crecimiento, la Probreza, y la Distribución del Ingreso. Guatemala City: F \& G Editores.

Segovia, Alexnder. 2005. Integración real y grupos de poder económico en América Central: Implicaciones para el desarrollo y la Democracia de la Región. San Jose: Fundación Friedrich Ebert América Central.

Sistema de Información Estadística sobre las Migraciones en Centroamérica (SIEMCA). 2004.

"Informes nacionales sobre migración internacional en países de Centroamérica”. Agosto. Santiago: United Nations.

Thomson, M. 1986. Women of El Salvador: The Price of Freedom. London: Zed Books. United Nations Development Programme (UNDP). 2005. Informe sobre Desarrollo Humano, El Salvador 2005: Una Mirada al Nuevo Nosotros/El Impacto de la Migraciones. San Salvador: UNDP.

Williams, Allan M. and Vladimir Baláz. 2005. "Winning, then Losing, the Battle with Globalization: Vietnamese Petty Traders in Slovakia.” International Journal of Urban and Regional Research 29:3: 533-549.

Williams, Christine L. and Chandra Muller and Kristine Kilanski. 2012. "Gendered Organizations in the New Economy." Gender \& Society 26: 549-573. 
White, Alastair. El Salvador (Nations of the modern world). Charlottesville, VA: Ernest Benn and The University of Virginia.

Yukseker, Deniz. 2004. "Trust and Gender in a Transnational Market: The Public Culture of Laleli, Istanbul.” Public Culture 16:1: 47-65. 